\title{
Knocking Out P2X Receptors Reduces Transmitter Secretion in Taste Buds
}

\author{
Yijen A. Huang, ${ }^{1}$ Leslie M. Stone, ${ }^{3,4}$ Elizabeth Pereira, ${ }^{1}$ Ruibiao Yang, ${ }^{4,7}$ John C. Kinnamon, ${ }^{4,7}$ Gennady Dvoryanchikov, ${ }^{1}$ \\ Nirupa Chaudhari, ${ }^{1,2}$ Thomas E. Finger, ${ }^{4,5}$ Sue C. Kinnamon, ${ }^{3,4,6}$ and Stephen D. Roper ${ }^{1,2}$ \\ ${ }^{1}$ Department of Physiology and Biophysics and 2Program in Neuroscience, Miller School of Medicine, University of Miami, Miami, Florida 33136, \\ ${ }^{3}$ Department of Biomedical Sciences, Colorado State University, Fort Collins, Colorado 80523, ${ }^{4}$ Rocky Mountain Taste and Smell Center and Departments of \\ ${ }^{5}$ Cell and Developmental Biology and ${ }^{6}$ Otolaryngology, University of Colorado School of Medicine, Aurora, Colorado 80045, and ${ }^{7}$ Department of Biological \\ Sciences, University of Denver, Denver, Colorado 80208
}

In response to gustatory stimulation, taste bud cells release a transmitter, ATP, that activates $\mathrm{P} 2 \mathrm{X} 2$ and $\mathrm{P} 2 \mathrm{X} 3$ receptors on gustatory afferent fibers. Taste behavior and gustatory neural responses are largely abolished in mice lacking P2X2 and P2X3 receptors [P2X2 and P2X3 double knock-out (DKO) mice]. The assumption has been that eliminating P2X2 and P2X3 receptors only removes postsynaptic targets but that transmitter secretion in mice is normal. Using functional imaging, ATP biosensor cells, and a cell-free assay for ATP, we tested this assumption. Surprisingly, although gustatory stimulation mobilizes $\mathrm{Ca}^{2+}$ in taste Receptor (Type II) cells from DKO mice, as from wild-type (WT) mice, taste cells from DKO mice fail to release ATP when stimulated with tastants. ATP release could be elicited by depolarizing DKO Receptor cells with $\mathrm{KCl}$, suggesting that ATP-release machinery remains functional in DKO taste buds. To explore the difference in ATP release across genotypes, we used reverse transcriptase (RT)-PCR, immunostaining, and histochemistry for key proteins underlying ATP secretion and degradation: Pannexin1, TRPM5, and NTPDase2 (ecto-ATPase) are indistinguishable between WT and DKO mice. The ultrastructure of contacts between taste cells and nerve fibers is also normal in the DKO mice. Finally, quantitative RT-PCR show that P2X4 and P2X7, potential modulators of ATP secretion, are similarly expressed in taste buds in WT and DK0 taste buds. Importantly, we find that P2X2 is expressed in WT taste buds and appears to function as an autocrine, positive feedback signal to amplify taste-evoked ATP secretion.

\section{Introduction}

Taste buds are specialized chemoreceptive organs that transduce chemical stimuli and transmit the information to gustatory afferent fibers. Several neurotransmitter candidates have been proposed for synapses in taste buds, including acetylcholine, ATP, glutamate, norepinephrine (NE), serotonin (5-HT), GABA, and a number of peptides (Nagahama and Kurihara, 1985; Nagai et al., 1998; Ogura, 2002; Lu et al., 2003; Kaya et al., 2004; Finger et al., 2005; Huang et al., 2005, 2007, 2008a; Shen et al., 2005; Zhao et al., 2005; Romanov et al., 2007; Shin et al., 2008; Cao et al., 2009; Dando et al., 2010; Murata et al., 2010; Starostik et al., 2010; Dvoryanchikov et al., 2011). Of these, definitive evidence for taste-evoked transmitter release only exists for ATP, norepineph-

Received June 30, 2011; accepted July 31, 2011.

Author contributions: Y.A.H., L.M.S., J.C.K., G.D., N.C., T.E.F., S.C.K., and S.D.R. designed research; Y.A.H., L.M.S., E.P., R.Y., J.C.K., G.D., N.C., T.E.F., and S.C.K. performed research; N.C., T.E.F., S.C.K., and S.D.R. contributed unpublished reagents/analytic tools; Y.A.H., L.M.S., E.P., R.Y., J.C.K., G.D., N.C., T.E.F., S.C.K., and S.D.R. analyzed data; Y.A.H., L.M.S., J.C.K., G.D., N.C., T.E.F., S.C.K., and S.D.R. wrote the paper.

Funding was provided by grants from NIH/NIDCD, including R01DC007495 and P30DC004657 (T.E.F. and S.C.K.), R01DC006308 (N.C.), 5 R01DC000374 (S.D.R.), and 2R01DC007630 (S.D.R.). We are grateful to Debra Cockayne of Roche Biosciences, who made the double knock-out mice and their wild-type controls available for our study. We thank Dr. Emily Liman for the TrpM5 antibody, Catherine Anderson, Danielle Boisvert, and Jason Parnes for technical assistance.

Correspondence should be addressed to Dr. Stephen Roper, Department of Physiology and Biophysics, University of Miami School of Medicine, 1600 NW 10th Avenue, Miami, FL 33136. E-mail: sroper@med.miami.edu.

DOI:10.1523/JNEUROSCI.3356-11.2011

Copyright $\odot 2011$ the authors $\quad 0270-6474 / 11 / 3113654-08 \$ 15.00 / 0$ rine, serotonin, and GABA (Finger et al., 2005; Huang et al., 2005, 2007, 2008a; Romanov et al., 2007; Murata et al., 2010; Huang and Roper, 2011). Specifically, Finger et al. (2005) used a luciferin-luciferase-based assay to detect ATP released from intact taste epithelium while Huang et al. (2007), Romanov et al. (2007), and Murata et al. (2010) measured ATP release on a cellular level to establish that taste bud Receptor (Type II) cells secrete ATP in response to gustatory stimulation. This transmitter release was via a novel mechanism-secretion through gap junction hemichannels, likely composed of pannexin 1 (Huang et al., 2007; Dando and Roper, 2009). Further, Huang et al. (2007, 2008a, 2009) showed that Presynaptic (Type III) taste cells release serotonin, or serotonin with norepinephrine, when they are stimulated by acidic tastants or by ATP released from adjacent taste Receptor cells (also see Dvoryanchikov et al., 2007). These findings highlight the importance of ATP as a taste transmitter.

Sensory axons innervating taste buds express two ionotropic P2X receptor subunits: P2X2 and P2X3 (Bo et al., 1999). In a key paper, Finger et al. (2005) established that ATP signaling via these $\mathrm{P} 2 \mathrm{X}$ receptors was necessary for successful transmission of information from taste cells to the sensory axons that innervate taste buds. These studies showed that taste-evoked responses recorded from gustatory nerves innervating taste buds were abolished and behavioral responses to most taste modalities lost in mice lacking both P2X2 and P2X3 purinoceptors [double knock-out (DKO) mice], but not in mice lacking only one of these receptors. These 
Table 1. Primers for end-point and quantitative RT-PCR, annealing temperature (Annl., ${ }^{\circ} \mathrm{C}$ ), and $\mathrm{PCR}$ product length (Prod, bp)

\begin{tabular}{|c|c|c|c|c|c|c|}
\hline Figure & Protein/gene & Accession \# & Forward primer $\left(5^{\prime} \rightarrow 3^{\prime}\right)$ & Reverse primer $\left(5^{\prime} \rightarrow 3^{\prime}\right)$ & Prod, bp & Annl., ${ }^{\circ} \mathrm{C}$ \\
\hline \multicolumn{7}{|c|}{ Controls } \\
\hline 7 & Keratin8/Krt8 & NM_031170 & cagagggcatcgttggag & tcatgttctgcatcccagac & 250 & 60 \\
\hline 7 & Keratin20/Krt20 & NM_023256 & gaggcccaactgatgcagat & ccttgacttcagaggacacgac & 249 & 58 \\
\hline 7 & $\mathrm{PLC} \beta 2 / P / c b 2$ & NM_177568 & gagcaaatcgccaagatgat & ccttgtctgtggtgaccttg & 163 & 60 \\
\hline 4 & Px1/Panx1 & NM_019482 & cattgaccccatgctactcc & tcagccacagaagtcacagg & 249 & 60 \\
\hline 7 & SNAP25 /Snap25 & NM_011428 & ggcaataatcaggatggagtag & agatttaaccacttcccagca & 310 & 58 \\
\hline 4 & TrpM5/Trpm5 & NM_020277 & gtctggaatcacaggccaac & gttgatgtgсcссаaаaаct & 234 & 60 \\
\hline \multicolumn{7}{|c|}{$\mathrm{P} 2 \mathrm{X}$ receptors } \\
\hline 7 & $P 2 \times 1 / P 2 r x 1$ & NM_008771 & ggtggaggaggtgaatggta & caggttcttctccecgtaca & 241 & 60 \\
\hline 7 & $\mathrm{P} 2 \times 2 / P 2 r \times 2$ & NM_153400 & caccaccactcgaactctca & ggtacgcaccttgtcgaact & 217 & 60 \\
\hline 7 & $\mathrm{P} 2 \mathrm{X} 3 / \mathrm{P} 2 \mathrm{rx} 3$ & NM_145526 & caaagccaggaagtttgagg & gttctgcagcccaaggataa & 179 & 60 \\
\hline 7 & $\mathrm{P} 2 \mathrm{X} 4 / \mathrm{P} 2 \mathrm{rx} 4$ & NM_011026 & cgctttgacatcatcgtgtt & tgctcgtagtcttccacatactt & 200 & 60 \\
\hline 7 & $\mathrm{P} 2 \times 5 / P 2 r \times 5$ & NM_033321 & gggctttcttctgtgacctg & gtgatggcttcatgttcaag & 294 & 60 \\
\hline 7 & P2X6/P2rx6 & NM_011028 & ttcaggacagccaatcactg & gtaacagggttagcgggtga & 314 & 60 \\
\hline 7 & P2X7/P2rx7 & NM_011027 & ccctgcacagtgaacgagta & cgtggagagatagggacagc & 217 & 60 \\
\hline
\end{tabular}

data were interpreted as indicating that postsynaptic receptors for taste transmitters were eliminated by the gene knock-out, thereby implicating ATP as a likely transmitter between gustatory receptor cells and afferent fibers. It was assumed that taste transmitter release was still normal since the $\mathrm{P} 2 \mathrm{X} 2$ and $\mathrm{P} 2 \mathrm{X} 3$ receptors had been identified previously only on the postsynaptic afferent fibers (Bo et al., 1999).

To test this assumption, we investigated whether transmitter release and other key properties of taste transduction are normal in mutant mice lacking $\mathrm{P} 2 \mathrm{X} 2$ and $\mathrm{P} 2 \mathrm{X} 3$ receptors. By measuring released ATP using a luciferin/luciferase-based assay as well as Fura 2 $\mathrm{Ca}^{2+}$ imaging with cellular biosensors, we examined taste-evoked ATP secretion from taste buds of WT, P2X2, and P2X3 DKO mice. Unexpectedly, our findings indicate that in addition to the previously demonstrated postsynaptic defect in taste afferent neurons, tastant-evoked release of ATP from taste buds themselves is disrupted in mice with genetic deletion of the $\mathrm{P} 2 \mathrm{X} 2$ and $\mathrm{P} 2 \mathrm{X} 3$ receptors.

\section{Materials and Methods}

Animals. We used adult P2X2 and P2X3 DKO mice of either sex, along with the control WT line of similar background (mixed C57BL6 and Ola) as in the previous study (Finger et al., 2005). For some experiments (e.g., validation of antisera), we used C57BL/6J mice. No differences were observed when using the different wild-type control lines. For functional studies, mice were killed with $\mathrm{CO}_{2}$ followed by cervical dislocation before tongues were removed. For histological studies, mice were anesthetized and perfused transcardially with fixative as detailed below. All experimental protocols were performed following National Institutes of Health guidelines as approved by the Institutional Animal Care and Use Committees of University of Miami, University of Colorado Denver, University of Denver, and Colorado State University.

Luciferin/luciferase experiments. Lingual epithelium containing vallate papillae from adult wild-type and DKO mice were collected for luciferin/ luciferase experiments as previously described (Finger et al., 2005). For each experiment, the peeled lingual epithelium was placed onto a plastic sheet such that the basal portion of the vallate papilla protruded through a rectangular area $(0.5 \mathrm{~mm} \times 1 \mathrm{~mm})$ into a well containing $100 \mu \mathrm{l}$ of Tyrode's solution (see below for composition). Tastants were applied to the mucosal surface of the lingual epithelium and Tyrode's solution bathing the basal portion of the vallate papilla was collected following application of the tastant. An equal amount of Luciferase reagent (Roche: ATP Bioluminescence Assay Kit HS II) was added to the samples and the combined solution was placed into a luminometer (Turner Biosystems $20 / 20^{\mathrm{n}}$ ) for analysis. Readings were collected as arbitrary relative light units (RLU) using the software provided with the luminometer. RLU data were converted into ATP concentrations using a calibration curve obtained before each experiment. All solutions were brought to room temperature before the start of each experiment. Taste stimuli consisted of a mixture of denatonium, $1 \mathrm{~mm}$; cycloheximide, $10 \mu \mathrm{m}$; and SC45647, $0.1 \mathrm{mM}$. Typically, $5 \mu \mathrm{l}$ of the taste mix was applied to the mucosal surface. As a control for mechanical stimulation, we applied $5 \mu \mathrm{l}$ of Tyrode's buffer. Experiments were blinded to prevent bias.

Biosensor cells. Chinese hamster ovary $(\mathrm{CHO})$ cells stably expressing 5- $\mathrm{HT}_{2 \mathrm{C}}$ receptors or $\mathrm{P} 2 \mathrm{X} 2$ and $\mathrm{P} 2 \mathrm{X} 3$ receptors (hereafter, "5-HT-" or "ATP-biosensor cells," respectively) were prepared as described previously (Huang et al., 2005, 2007). Biosensors were transferred into the recording chamber alongside freshly harvested taste buds or taste cells. Individual biosensors were drawn onto a fire-polished glass micropipette and positioned against a taste bud or cell to measure transmitter release during gustatory stimulation. In some experiments, we used CHO cells expressing only endogenous $\mathrm{P} 2 \mathrm{Y}$ receptors for biosensors to test whether BzATP, a P2X receptor agonist, elicits ATP secretion from isolated taste buds. In separate experiments, we verified that biosensor cells were not affected by bath-applied $\mathrm{KCl}$, taste stimuli, or any pharmacological agents used in this study. In particular, BzATP did not elicit responses in the P2Y-ATP biosensors.

Isolated taste cells. We removed lingual epithelium containing taste papillae from the tongue and harvested taste buds and taste cells as described previously, with slight modification (Huang and Roper, 2010). Briefly, lingual epithelium was removed from the tongue after subepithelial injection of enzyme mixture. Taste buds were isolated from the epithelium and for preparing individual taste cells, were transferred to a shallow chamber containing trypsin for additional incubation. Taste cells were disassociated from taste buds by gently triturating and transferred to a recording chamber. Taste buds and taste cells were superfused with Tyrode's solution (in mM; $140 \mathrm{NaCl}, 5 \mathrm{KCl}, 2 \mathrm{CaCl}_{2}, 1 \mathrm{MgCl}_{2}, 10 \mathrm{HEPES}$, 10 glucose, $10 \mathrm{Na}$-pyruvate, $5 \mathrm{NaHCO}_{3}$, pH 7.4, 310-320 mOsm).

$\mathrm{Ca}^{2+}$ imaging. Fura $2 \mathrm{Ca}^{2+}$ imaging was performed using Workbench v5 software (Indec). F340/F380 was converted to $\left[\mathrm{Ca}^{2+}\right]_{\mathrm{i}}$ as described by Grynkiewicz et al. (1985). The fluorescence ratios of free and $\mathrm{Ca}^{2+}$ bound Fura 2 were determined using a Fura 2 Calcium Imaging Calibration Kit (Invitrogen). Isolated taste cells with resting $\left[\mathrm{Ca}^{2+}\right]_{\mathrm{i}}>200$ nm were excluded from the analyses (Hacker and Medler, 2008; Huang and Roper, 2010). The average resting $\left[\mathrm{Ca}^{2+}\right]_{\mathrm{i}}$ in these experiments was $154 \pm 11 \mathrm{~nm}$.

Stimulation. Isolated taste buds and/or cells were stimulated by bathperfusion of taste mix (cycloheximide, $10 \mu \mathrm{M}$; saccharin, $2 \mathrm{~mm}$; SC45647, $0.1 \mathrm{~mm}$; denatonium, $1 \mathrm{~mm}$ ). For some experiments, taste buds were depolarized with increasing concentrations of $\mathrm{KCl}(50,100$, and $140 \mathrm{~mm}$ substituted equimolar for $\mathrm{NaCl}$ ), or taste mix paired with $50 \mathrm{~mm} \mathrm{KCl}$ (Huang and Roper, 2010). All stimuli were in Tyrode's solution and applied at pH 7.2 unless otherwise noted. BzATP was purchased from Sigma. All solutions were at room temperature.

Quantification and data analysis of $\mathrm{Ca}^{2+}$ imaging. The quantification of responses is described by Huang et al. (2009). Briefly, we recorded the resting baseline for 30-60 s before each stimulus. Stimuli were applied for $30 \mathrm{~s}$ after which the perfusion was returned to Tyrode's solution. A minimum of 3-5 min was allowed between stimuli if repeated tests were 
A
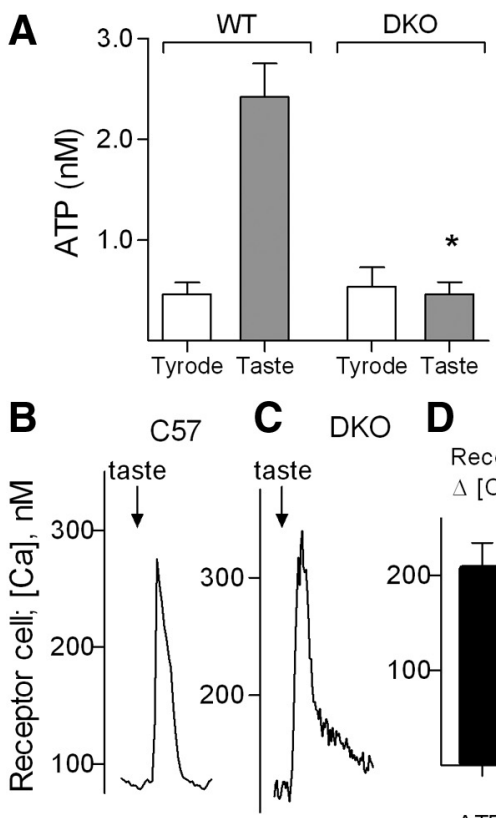

D

Receptor cell $\Delta\left[\mathrm{Ca}^{2+}\right]_{i}, \mathrm{nM}$
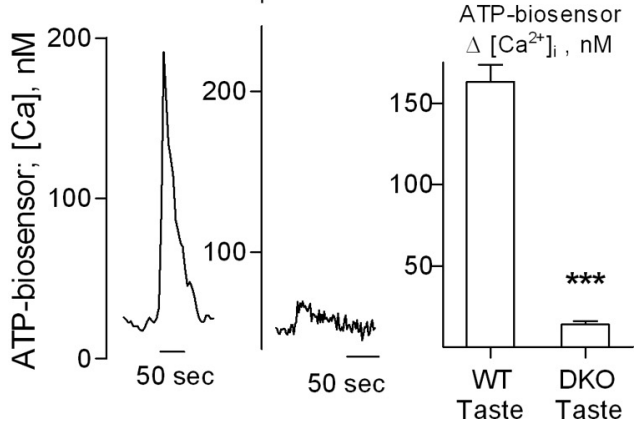

Figure 1. Taste-evoked ATP secretion from taste buds is significantly reduced in double knock-out mice lacking P2X2 and P2X3 receptors (DK0 mice). $A$, Luciferase assay of ATP secretion from pieces of lingual epithelium containing vallate papillae. Open bars, Lingual epithelium was stimulated with Tyrode solution; filled bars, stimulation with taste mixture. Data from DKO mice (right) show no taste-stimulated ATP secretion. Ordinate, ATP secreted, nм (WT Taste vs. DKO Taste, ${ }^{*} p<0.05$, Student's t test). $\boldsymbol{B}-\boldsymbol{D}$, Fura $2 \mathrm{Ca}^{2+}$ imaging and biosensor assay of ATP secreted from identified Receptor (Type II) taste cells. $\boldsymbol{B}$, Traces from a Receptor cell (upper) and concurrent recording from an ATP biosensor (lower) from a C57BJ/6l (wild-type) mouse, showing taste-evoked responses in the Receptor cell and taste-evoked ATP secretion (biosensor trace). Ordinates, Intracellular $\mathrm{Ca}^{2+}$ mobilization, nM. Arrows in this and following figures indicate $30 \mathrm{~s}$ bath application of stimulus. C, A similar experiment from a Receptor cell from a DKO mouse. Although taste stimulation evoked a robust $\mathrm{Ca}^{2+}$ response in the Receptor cell, ATP secretion was greatly reduced. $\boldsymbol{D}$, Summary of results. Filled bars (top), $\mathrm{Ca}^{2+}$ mobilization in Receptor cells; open bars (bottom), ATP biosensor responses; wild-type mice, $N=16$; DKO mice, $N=17 ;{ }^{* * *} p<0.001$, Student's $t$ test.

conducted. This protocol is efficient for eliciting responses without desensitization. Statistical analyses using paired Student's $t$ tests were applied to determine whether changes in responses following a given treatment were significant. Data presented in bar graphs show means \pm SEM.

Immunohistochemistry. Mice were anesthetized with pentobarbital. For anti-pannexin, mice were perfused transcardially with PBS followed by $4 \%$ paraformaldehyde. The tongue was removed, postfixed for 1 hour, and transferred to $30 \%$ sucrose overnight. For anti-TRPM5, mice were perfused transcardially with $0.9 \%$ saline solution followed by a periodatelysine-paraformaldehyde (PLP) fixative containing $75 \mathrm{~mm}$ lysine, $10 \mathrm{~mm}$ sodium periodate, and $1.6 \%$ paraformaldehyde. The tongue was removed, postfixed for $2 \mathrm{~h}$, and transferred into $0.1 \mathrm{M}$ PBS with $25 \%$ sucrose overnight. For immunolabeling, tissue blocks were embedded in optimal cutting temperature (OCT) compound (Sakura Finetek USA).

Sections were incubated with anti-pannexin 1 antibodies (generated against recombinant amino acids sequence corresponding to $135-165$ of the intracytoplasmatic loop of the mouse Pannexin1 protein expressed in
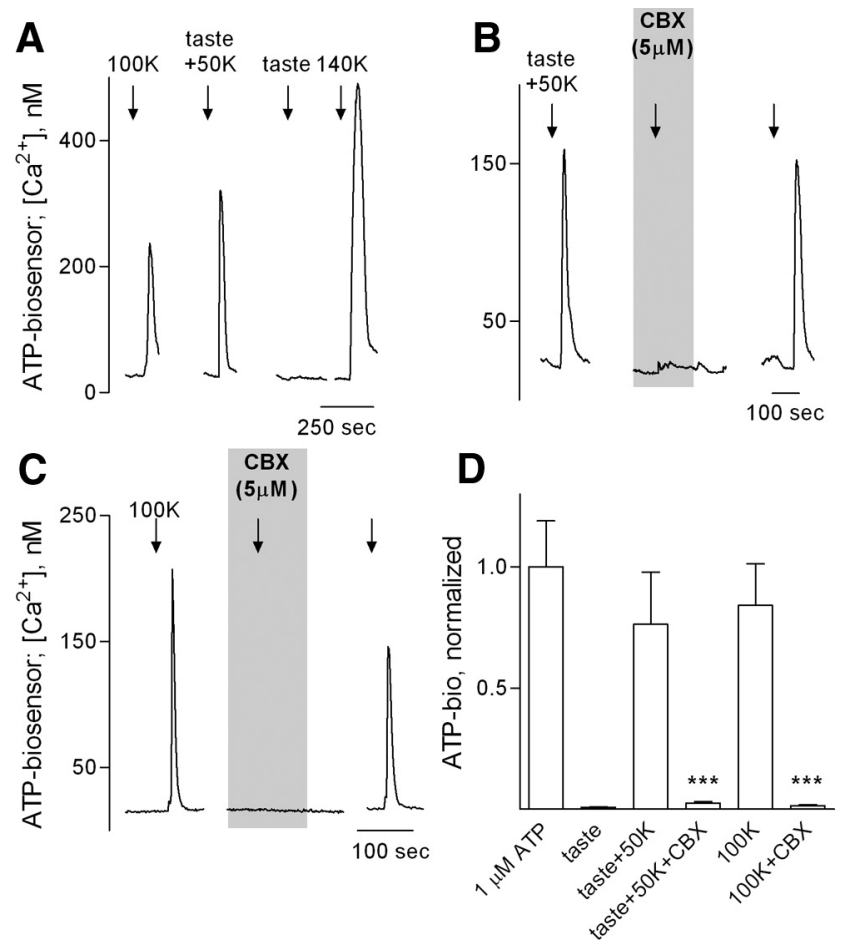

Figure 2. Strong depolarization rescues taste-evoked ATP secretion from taste buds of DKO mice. $A$, Traces show recordings from an ATP biosensor closely apposed to a taste bud isolated from a DKO mouse. Bath-applied KCI (100 and $140 \mathrm{~mm}$ ) evoked robust biosensor responses (i.e., ATP secretion). If taste stimulation was paired with milder depolarization ( $50 \mathrm{~mm} \mathrm{KCI),} \mathrm{ATP}$ secretion was also observed ( $50 \mathrm{~mm} \mathrm{KCl}$ alone or taste alone did not elicit ATP secretion). B, C, ATP secretion evoked by taste plus $\mathrm{KCl}(50 \mathrm{~mm})$ or $\mathrm{KCl}(100 \mathrm{~mm})$ was abolished by $5 \mu \mathrm{m}$ carbenoxolone (shaded area), a Px1 hemichannel antagonist at the concentration used. D, Summary of data for taste- and KCl-evoked ATP secretion from taste buds of DKO mice. Bars show mean \pm SEM of $\mathrm{Ca}^{2+}$ responses in ATP biosensor cells, normalized to biosensor responses to $1 \mu \mathrm{M}$ ATP. $N=5 ;{ }^{* * *} p<0.001$, Student's $t$ test.

Escherichia coli; chicken anti-Px1, ANT0027; Diatheva; diluted 1:2000 and processed with TSA amplification, Invitrogen) or a 1:500 dilution of TRPM5 antibody (provided by Emily Liman, Department of Biological Sciences, University of Southern California, Los Angeles, CA). Sections were then washed and reacted with secondary antiserum, horseradish peroxidase-labeled goat anti-chicken (Aves Labs Cat H-1004, concentration 1: 500) or Alexa 568 goat anti-rabbit IgG (1:400; Invitrogen) for $2 \mathrm{~h}$ at room temperature.

$R T-P C R$. Tissue was isolated from the foliate and circumvallate papillae and pooled from six adult wild-type and DKO mice. RNA was extracted according to the manufacturer's instructions using the RNeasy Micro kit from Qiagen, including a $2 \mathrm{~h}$ DNase I treatment at room temperature for removal of genomic DNA. Reverse transcription was performed using the iScript cDNA Synthesis kit from Biorad using primers in Table 1. Reactions were set up in which the reverse transcriptase enzyme was omitted as a control to test for DNA contamination. Two microliters of cDNA were added to the PCR (Qiagen TaqPCR Core kit). PCR conditions included an initial 5 min denaturation step followed by 35 cycles of $30 \mathrm{~s}$ denaturation at $95^{\circ} \mathrm{C}, 30 \mathrm{~s}$ annealing at $60^{\circ} \mathrm{C}$, and $45 \mathrm{~s}$ extension at $72^{\circ} \mathrm{C}$; concluding with a $7 \mathrm{~min}$ final extension step. We included cDNA from nontaste lingual epithelium and a no template control (water). Amplified sequences were visualized by gel electrophoresis in $2 \%$ agarose gels stained with GelRed (Biotium). The nontaste lingual epithelium was determined to be free of taste buds via RT-PCR for $\alpha$-gustducin and PLC $\beta 2$ expression (data not shown). Experiments were repeated three independent times.

Real-time RT-PCR. Real-time RT-PCR for P2X receptors and controls was performed as described previously (Dvoryanchikov et al., 2007) using taste bud cDNA of three DKO and WT mice. Each cDNA was quantified in triplicate for every gene analyzed. 
Ecto-ATPase histochemistry. DKO mice were anesthetized and perfused transcardially with $2 \%$ paraformaldehyde and $0.2 \%$ glutaraldehyde in 0.1 Tris-maleate buffer, $\mathrm{pH}$ 7.4. After $1 \mathrm{~h}$ postfix, lingual tissue was transferred to $20 \%$ sucrose in the same buffer. Frozen sections $(16 \mu \mathrm{m})$ were rinsed in $0.07 \mathrm{M}$ Tris maleate buffer and incubated for $30 \mathrm{~min}$ in detection solution containing $2 \mathrm{~mm} \mathrm{~Pb}\left(\mathrm{NO}_{3}\right)^{2}, 1 \mathrm{~mm}$ levamisole, $1 \mathrm{~mm}$ ouabain, $50 \mu \mathrm{M} \alpha, \beta$-methylene ADP, $5 \mathrm{~mm} \mathrm{KCl,} 2 \mathrm{~mm} \mathrm{CaCl}_{2}$, and $1 \mathrm{~mm}$ either ATP or ADP (all from Sigma). The lead precipitate was visualized with $1 \%$ ammonium sulfide in buffer. As shown previously (Barry, 1992; Bartel et al., 2006), taste-bud associated precipitate was present only following incubation with ATP and not after ADP, indicating the high specificity for ATP.

Electron microscopy. Mice were anesthetized and perfused for transmission electron microscopy (Kinnamon et al., 1988). The tissues were cut into $200 \mu \mathrm{m}$ thickness sections with a Vibratome. After rinsing in buffer the sections were osmicated for $1 \mathrm{~h}$ in $1 \% \mathrm{OsO}_{4}$ in $0.05 \mathrm{M}$ cacodylate buffer at $4^{\circ} \mathrm{C}$. Sections were stained en bloc in $1 \%$ uranyl acetate and embedded with Eponate 12 (Ted Pella). The sections were re-embedded using the technique of Crowley and Kinnamon (1995). Thin sections (90$120 \mathrm{~nm}$ ) were cut and examined with a HITACHI H-7000 electron microscope.

\section{Results}

Using a luciferin/luciferase-based bioluminescence assay, we tested the ability of lingual tissue containing taste buds to release ATP. As shown previously (Finger et al., 2005), stimulating epithelial pieces containing vallate papillae from wild-type mice with tastants elicited a significant release of ATP $(2.42 \pm 0.33 \mathrm{nM})$ relative to stimulation with buffer alone $(0.463 \pm 0.118 \mathrm{~nm})$ (means \pm SEM, $N=3$ each; $p<0.05$ ). Stimulation of equivalent size pieces of nongustatory epithelium with the taste mixture evoked little or no ATP release above baseline levels (data not shown). In contrast, we observed little or no taste-evoked ATP secretion from taste epithelium of DKO mice (buffer stimulation, $0.57 \pm 0.19 \mathrm{nM}$ vs taste stimulation, $0.460 \pm 0.124 \mathrm{nM} ; N=3$ ). The small amount of ATP released from tissue of DKO mice is consistent with mechanical stimulation.

To examine taste-evoked ATP release in greater detail, we isolated individual taste cells from DKO mice and used biosensors to monitor transmitter secretion. We identified isolated taste Receptor (Type II) cells from wild-type and DKO mice by virtue of the fact that Receptor cells show a robust $\left[\mathrm{Ca}^{2+}\right]_{\mathrm{i}}$ mobilization in response to taste stimulation but do not respond to depolarization with $\mathrm{KCl}$ (50 mM) (DeFazio et al., 2006). Isolated taste Receptor cells from wild-type and DKO mice alike responded to taste stimuli with increases in intracellular $\mathrm{Ca}^{2+}$ (Fig. $1 B-D$, top). However, concurrent biosensor measurement of tasteevoked ATP secretion from Receptor cells (Fig. $1 B-D$, bottom) revealed significantly reduced ATP secretion in DKO mice relative to wild type.

Taste Receptor cells in wild-type mice (C57BL/6J) are capable of secreting ATP in the absence of taste stimulation and without $\mathrm{Ca}^{2+}$ mobilization if they are sufficiently depolarized (Romanov et al., 2008; Huang and Roper, 2010). Surprisingly, in taste buds isolated from DKO mice, $\mathrm{KCl}$ depolarization $(100 \mathrm{~mm}$ and higher) elicited ATP secretion as in wild-type mice (Huang and Roper, 2010) (Fig. 2). Depolarization with $50 \mathrm{~mm} \mathrm{KCl}$ alone does not release ATP from WT or DKO taste buds (data not shown). Furthermore, taste-evoked ATP secretion from isolated taste buds could be rescued in DKO mice when taste stimulation was combined with depolarization $(\mathrm{KCl}, 50 \mathrm{~mm}$ ) (Fig. $2 \mathrm{~A}$ ). In all cases, ATP secretion from taste buds isolated from DKO mice, whether evoked by strong $\mathrm{KCl}$ depolarization $(\geq 100 \mathrm{mM}$ ) or taste stimulation plus mild depolarization $(50 \mathrm{~mm} \mathrm{KCl})$, was blocked by a low concentration of carbenoxolone $(5 \mu \mathrm{M})$, consistent with
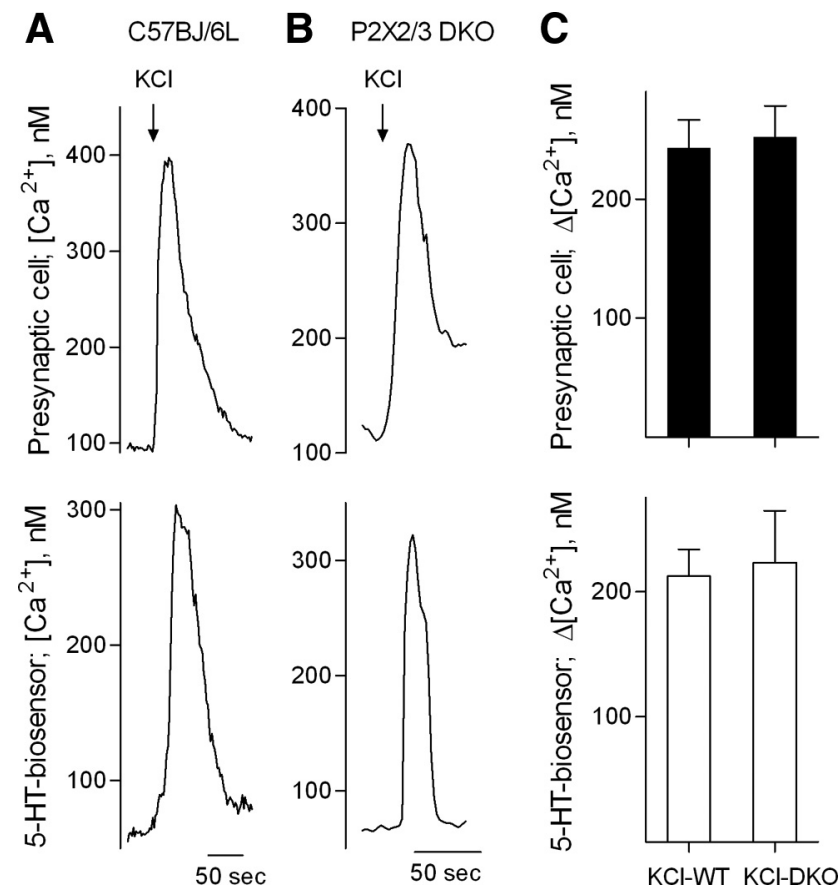

Figure 3. Transmitter (serotonin) secretion from Presynaptic (Type III) taste cells of DKO mice is normal. Serotonin (5-HT) biosensor cells were used to record taste-stimulated 5-HT release from Presynaptic cells in wild-type and DKO mice. $\boldsymbol{A}$, Traces from a wild-type mouse; depolarization with $\mathrm{KCl}(50 \mathrm{~mm})$ evoked a marked $\mathrm{Ca}^{2+}$ response from a Presynaptic cell (upper trace) and concurrent response from a 5 - $\mathrm{HT}$ biosensor in close proximity to the Presynaptic cell (lower trace). $\boldsymbol{B}$, Data from a DKO mouse: recordings show depolarization-evoked response in the Presynaptic cell (upper) and concurrent 5-HT release (lower), just as in wild-type mouse. $\boldsymbol{C}$, Summary of data from Presynaptic/biosensor cells. Filled bars (above), depolarization-evoked $\mathrm{Ca}^{2+}$ responses in Presynaptic cells $(50 \mathrm{~mm} \mathrm{KCl})$. Open bars (below), 5-HT release (biosensor cell responses). Wild-type mice, $N=14$; DKO mice, $N=8$. Depolarization evoked 5-HT release from taste cells of DKO mice is indistinguishable from that of taste cells of wild-type mice.

ATP efflux through pannexin1 hemichannels in DKO and wildtype mice alike (Fig. 2B-D) (Huang et al., 2007; Dando and Roper, 2009).

In summary, taste stimulation fails to trigger significant ATP secretion from taste buds of DKO mice. However, taste-evoked ATP release can be rescued in the DKO mice if taste cells are sufficiently depolarized with $\mathrm{KCl}$. Strong depolarization alone also can elicit ATP secretion from Receptor cells isolated from DKO mice.

We next tested whether transmitter release from Presynaptic (Type III) taste cells was similarly depressed in DKO mice. Presynaptic (Type III) taste cells normally release serotonin (5-HT) in response to exposure to sour tastants, $\mathrm{KCl}$ depolarization, or ATP released from Receptor (Type II) taste cells (Huang et al., 2007, 2008b) (Fig. 3A). Presynaptic cells from DKO mice responded normally to $\mathrm{KCl}$ depolarization with 5 -HT release (Fig. $3 B$, top). Concurrent measurement of 5 -HT release from Presynaptic cells showed no difference between DKO mice and WT mice (Fig. 3, bottom). Similarly, bath-applied ATP $(1 \mu \mathrm{M})$ also evoked 5-HT release from Presynaptic cells that was indistinguishable between DKO and WT mice (data not shown).

In an attempt to identify why knocking out P2X2 and P2X3 receptor expression eliminated normal taste-evoked ATP secretion, we examined Receptor cells from DKO mice for the presence of two key elements in transmitter secretion-TRPM5 cation channels (Zhang et al., 2007; Huang and Roper, 2010) and pannexin 1 gap junction hemichannels (Huang et al., 2007; Romanov et al., 2007; Dando and Roper, 2009). There were no 
obvious differences between wild-type and DKO mice either in the gross histology, in Pannexin 1 immunostaining (Fig. $4 A, B)$, or in TRPM5 immunopositivity (Fig. 4C).

These immunohistochemical results were confirmed by RT-PCR. DKO and WT mice showed similar expression of Px1 and TRPM5 in taste epithelium and their absence from adjacent nontaste epithelium (Fig. 4D).

In WT mice, taste buds express robust ecto-ATPase activity, likely needed to inactivate the ATP released following taste stimulation (Bartel et al., 2006). Because DKO mice are defective in ATP release, we tested whether ecto-ATPase is present and active in taste tissues from DKO mice. Ecto-ATPase histochemistry showed a typical pattern and density of staining in DKO and WT tissue (Fig. 4E).

We next examined the ultrastructure of contacts between taste cells and afferent nerve fibers. In taste buds from WT mice, Presynaptic (Type III) cells form readily identifiable synapses complete with synaptic vesicles and thickened presynaptic and postsynaptic membranes. In contrast, no clear ultrastructural specializations resembling synapses exist between Receptor (Type II) cells and nerve fibers (Murray, 1993), consistent with transmitter release via Px1 gap junction hemichannels (Huang et al., 2007; Romanov et al., 2007; Dando and Roper, 2009). Instead, there often are atypical enlarged mitochondria in Receptor cells where nerve fibers come in proximity (Royer and Kinnamon, 1988). As shown in Figure 5, Presynaptic (Type III) cells in the DKO mice, as in WT mice, have distinct synapses (Fig. 5A) while Receptor

(Type II) cells exhibit large mitochondria with tubular cristae at close appositions with nerve processes (Fig. 5B). Thus, there were no ultrastructural abnormalities in the synaptic contacts of DKO mouse taste buds that could explain the absence of taste-evoked neurotransmission.

In a final attempt to resolve why taste-evoked ATP secretion in $\mathrm{P} 2 \mathrm{X} 2$ and P2X3 DKO mice is significantly reduced, we reasoned that Receptor (Type II) cells might normally express P2X2 and/or $\mathrm{P} 2 \mathrm{X} 3$ receptors that would serve to boost ATP release during taste stimulation. The absence of such an autocrine positive feedback in DKO mice could explain the observation that taste buds in DKO mice fail to secrete ATP upon taste stimulation. We tested for functional P2X receptors by isolating Receptor cells from WT and DKO mice, bath-applying MRS2179 to block P2Y1 receptors that these cells express (Huang et al., 2009), and stimulating the cells with ATP. Any residual ATP-evoked $\mathrm{Ca}^{2+}$ mobilization would likely be generated by $\mathrm{Ca}^{2+}$ influx through $\mathrm{P} 2 \mathrm{X}$ channels, if present. Indeed, in 4 of 11 Receptor cells from WT mice, we observed marked ATP-evoked $\mathrm{Ca}^{2+}$ responses under these conditions (Fig. 6A,B). Moreover, the residual ATP-evoked responses were eliminated by removing $\mathrm{Ca}^{2+}$ from the bath (i.e., eliminating $\mathrm{Ca}^{2+}$ influx) but were unaffected by blocking intra-
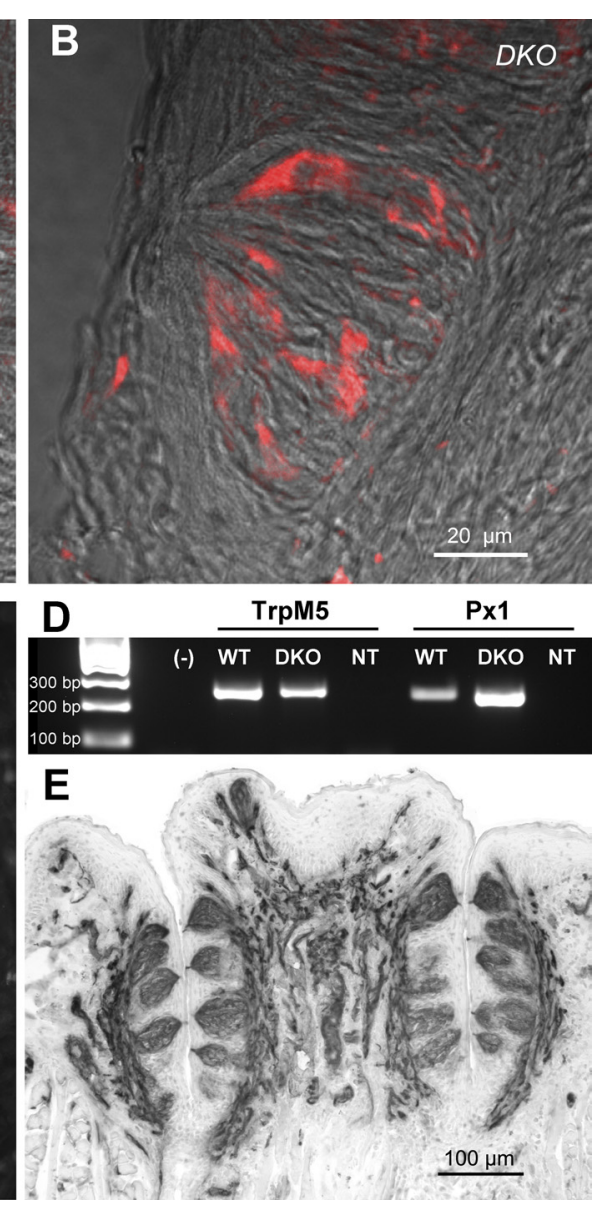

$50 \mu \mathrm{m}$
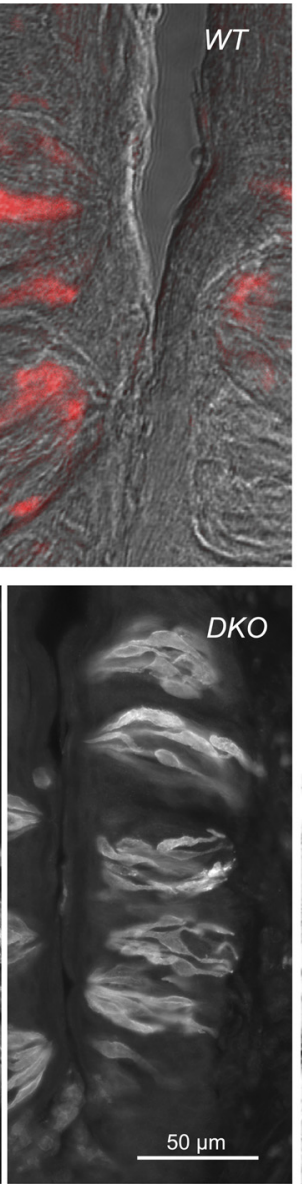

Figure 4. Expression of key elements for taste-evoked ATP release and degradation is similar between wild-type and DKO mice. 列 TrpM5 immunoreactivity in vallate papillae of a wild-type and a DKO mouse (WT, DKO). D, PCR for TRPM5 and Px1 from wild-type significantly between taste tissue from wild-type and DKO mice.

cellular store-release with the phospholipase C inhibitor, U73122 (i.e., eliminating contribution from P2Y-mediated $\mathrm{Ca}^{2+}$ mobilization). Both features are consistent with activation of $\mathrm{P} 2 \mathrm{X}$ receptors. In sharp contrast, 0 of 15 Receptor cells from DKO mice tested under identical conditions showed any signs of P2X-mediated responses (Fig. 6C,D). The difference in incidence of $\mathrm{P} 2 \mathrm{X}$-mediated responses between the two samples is significant at $p=0.022$ (Fisher's exact test).

Certain P2X receptors (most notably, P2X7) are known to interact with Px1 channels (Pelegrin and Surprenant, 2006). In taste buds, Px1 is the conduit for ATP release and P2X7 has been reported to be present (Hayato et al., 2007). To determine whether the expression of $\mathrm{P} 2 \mathrm{X} 7$ receptors is altered in DKO mice, we performed highly sensitive and quantitative RT-PCR. As reported by others (Hayato et al., 2007), we found that WT taste buds express P2X2, P2X4, and P2X7 (Fig. 7A). DKO taste buds only express P2X4 and P2X7. Using quantitative RT-PCR, we confirmed that $\mathrm{P} 2 \mathrm{X} 4$, and $\mathrm{P} 2 \mathrm{X} 7$ are expressed at very similar levels in WT and DKO mouse taste buds (Fig. 7B). Expression levels for control mRNAs, e.g., keratin 8, keratin 20, and Snap25 were also indistinguishable across the genotypes. PLC $\beta 2$ expression in DKO mice was lower than that in WT mice (Fig. $7 B$ ), a 


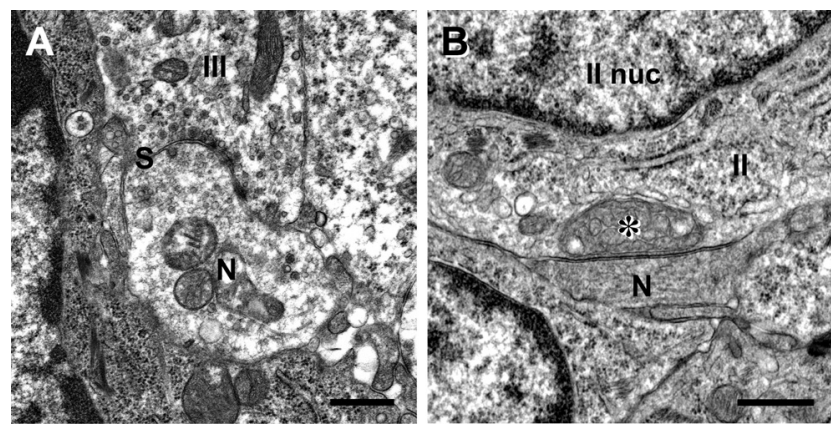

Figure 5. Ultrastructure of synapses in taste buds from DKO mice show no abnormalities. $\boldsymbol{A}$, Transmission electron micrograph showing a synapse (S) from a Type III (Presynaptic) cell (III) onto a nerve process (N) in a P2X2 and P2X3 DK0 mouse. Note the numerous presynaptic pleomorphic vesicles in the Type III cell. Scale bar, $0.5 \mu \mathrm{m}$. $\boldsymbol{B}$, An atypical mitochondrion $\left({ }^{*}\right)$ lies within the Receptor (Type II) cell (II) at its point of apposition with a nerve process (N) in a P2X2 and P2X3 DK0 mouse. Note the large size and tubular cristae of the atypical mitochondrion. This appearance is essentially identical to that in a wildtype mouse (Kinnamon et al., 1985). II nuc, Nucleus of the Type II cell. Scale bar, $0.5 \mu \mathrm{m}$.
A
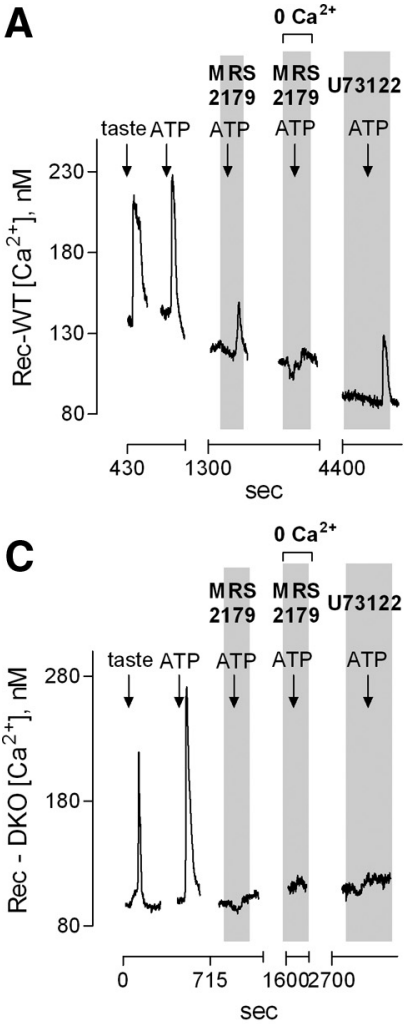

B

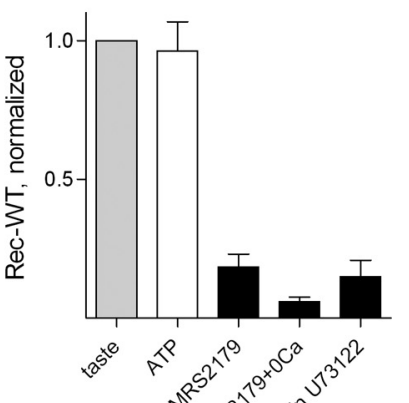

D

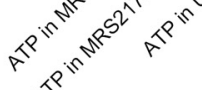
per

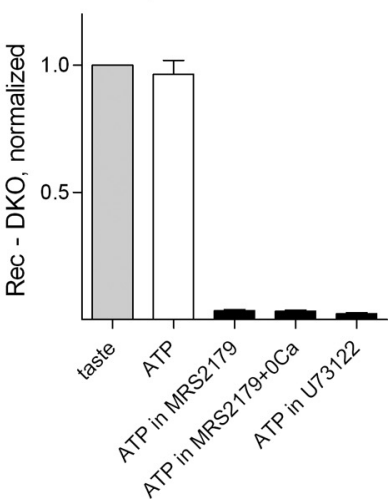

Figure 6. Taste Receptor (Type II) cells in wild-type mice express autocrine P2X receptors. $\boldsymbol{A}$, Trace showing continuous recording ( $>1 \mathrm{~h}$ duration) of Fura $2 \mathrm{Ca}^{2+}$ imaging from an identified Receptor cell isolated from a wild-type mouse, showing response to taste stimulation (arrow) followed by $\mathrm{Ca}^{2+}$ transients evoked by repeated applications of $1 \mu \mathrm{M}$ ATP (arrows) before and during MRS2179 $(10 \mu \mathrm{M})$ to block P2Y1 receptors, removal of $\mathrm{Ca}^{2+}$ from the bathing solution to eliminate $\mathrm{Ca}^{2+}$ influx, and lastly, in presence of U73122 (10 $\left.\mu \mathrm{M}\right)$ to block phospholipase C. $\boldsymbol{B}$, Summary of data from experiments as in $\boldsymbol{A}$, taken from 11 WT mouse Receptor cells. ATP-evoked $\mathrm{Ca}^{2+}$ responses were normalized to taste-evoked $\mathrm{Ca}^{2+}$ responses. Bars show means \pm SEM.C, $\mathrm{Ca}^{2+}$ imaging data from a Receptor taste cell isolated from a DKO mouse, parallel protocol as in A.D, Summary of data from 15 DKO mouse Receptor taste cells, as in $C$. result that was unexpected and that could contribute to taste differences between the two strains. However, note that tasteevoked mobilization of calcium, in which PLC $\beta 2$ participates, was similar in WT and DKO mice (Fig. $1 D$ ). Our expression data suggest that a relevant and important difference in taste buds between WT and DKO mice is the absence of P2X2. This channel could be a key contributor to the loss of taste-evoked ATP secretion in DKO mice.

A hypothesis that emerged consequent to these experiments is that during taste stimulation, Receptor cells secrete ATP, which acts postsynaptically as well as presynaptically (i.e., autocrine positive feedback) via $\mathrm{P} 2$ receptors, including $\mathrm{P} 2 \mathrm{X} 2$. Loss of this positive feedback in mice lacking $\mathrm{P} 2 \mathrm{X} 2$ receptors (i.e., DKO) could lead to a significant decline in transmitter output from Receptor cells. This hypothesis predicts that that in WT mice, activating P2X2 on Receptor cells should stimulate ATP release. Thus, we tested the actions of BzATP, a potent $\mathrm{P} 2 \mathrm{X} 2$ agonist, on taste buds from WT and DKO mice. Moreover, by using ATP biosensors that expressed only $\mathrm{P} 2 \mathrm{Y}$ receptors (insensitive to BzATP), we could monitor ATP release from BzATP-stimulated taste buds. We verified that such biosensors were not directly activated by BzATP (up to $30 \mu \mathrm{M}$ ). Indeed, BzATP $(0.3-3 \mu \mathrm{M}$ ) elicited ATP release from Receptor cells in WT mice (Fig. 7C,E). However, BzATP failed to elicit ATP secretion from Receptor cells in DKO mice (Fig. 7D,E). The magnitude of BzATPinduced ATP release was significantly different in WT versus DKO mice (Fig. 7E). BzATP at these concentrations is effective for P2X2 but not for P2X7, which is also present in taste buds from both WT and DKO mice. Together, these data suggest that Receptor cells might boost ATP secretion during taste stimulation by exciting autocrine $\mathrm{P} 2 \mathrm{X} 2$ receptors. Loss of $\mathrm{P} 2 \mathrm{X} 2$ receptors from Receptor cells as well as afferent nerves constitutes the cellular basis of taste failure in DKO mutant mice.

\section{Discussion}

ATP is a transmitter in mammalian taste buds, released from taste Receptor (Type II) cells when taste buds are stimulated by taste compounds. ATP is crucial for communication from taste buds to gustatory nerves (Finger et al., 2005) as well as for cell-cell communication within the taste bud (Huang et al., 2007; Dando and Roper, 2009). Our present results indicate that taste Receptor cells require functional $\mathrm{P} 2 \mathrm{X} 2$ receptors for normal transmitter release, most likely as autocrine receptors. When excited by taste stimuli, Receptor cells from mutant mice lacking P2X2 and P2X3 purinoceptors (double knock out, DKO, mice) secrete significantly less ATP than do Receptor cells from WT mice. Mice lacking P2X2 and $\mathrm{P} 2 \mathrm{X} 3$ receptors were previously shown to be taste-blind in nerve recordings and taste behavioral assays (Finger et al., 2005; Eddy et al., 2009; Hallock et al., 2009). The loss of taste in DKO mice was interpreted as due to the loss of postsynaptic purinoceptors, hence implicating ATP as a taste transmitter (Finger et al., 2005). The present study emphasizes that presynaptic functions - transmitter release - are also abnormal in DKO mice. Despite the reduction of ATP release, the anatomical and molecular features examined in taste buds from DKO mice appeared normal, and release of transmitter from Presynaptic cells (5-HT) was indistinguishable between DKO and WT mice.

The likely explanation for these unexpected findings is that $\mathrm{P} 2 \mathrm{X} 2$ receptors, in addition to their well established expression on postsynaptic sensory afferent fibers (Bo et al., 1999; Cheung and Burnstock, 2002; Finger et al., 2005; Kataoka et al., 2006; Hayato et al., 2007), are also present presynaptically on Receptor cells. Our data show that presynaptic $\mathrm{P} 2 \mathrm{X}$ receptors can produce 
autocrine positive feedback to stimulate ATP secretion, similar to the role of the autocrine $\mathrm{P} 2 \mathrm{Y} 1$ receptors there (Huang et al., 2009). Our data focused on P2X2 for which we could demonstrate expression in WT mice using RT-PCR. Neither we (here) nor Hayato et al. (2007) detected $\mathrm{P} 2 \mathrm{X} 3$ in wild-type taste buds. In a similar manner to what is proposed here, autocrine $\mathrm{P} 2 \mathrm{X}$ receptors on glucose-sensing pancreatic $\beta$ cells enhance insulin secretion (Jacques-Silva et al., 2010), and expression of autocrine $\mathrm{P} 2 \mathrm{X}$ receptors is a common theme for controlling ATP release at synapses in the nervous system (Dorostkar and Boehm, 2008). Further, P2X7 has been shown to complex with Px1 channels to influence secretion (Pelegrin and Surprenant, 2006), while P2X2 can functionally interact with nicotinic acetylcholine receptors (Decker and Galligan, 2010). Interestingly, P2X2 receptors are slower to desensitize than $\mathrm{P} 2 \mathrm{X} 3$, and are much more sensitive than P2X7 (North, 2002). Thus, P2X2 receptors would be optimal candidates for autocrine regulation of ATP secretion.

This interpretation of the findings would readily explain why in the absence of $\mathrm{P} 2 \mathrm{X} 2$ receptors (i.e., in DKO mice), taste-evoked depolarization is insufficient to reach levels required to fully open Px1 hemichannels for ATP release (Huang and Roper, 2010). It would also explain why slightly depolarizing taste buds with $50 \mathrm{~mm} \mathrm{KCl}$ would rescue transmitter release and lead to a burst of ATP release in DKO mice (Fig. 3). Of course, ATP could also be a paracrine stimulus for adjacent Receptor cells: ATP released by one Receptor cell during taste activation might recruit neighboring Receptor cells, leading to two or more cells being activated. In short, taste-evoked transmitter release and signal output from taste buds appears to be controlled by a host of factors, including (1) positive feedback from $\mathrm{P} 2 \mathrm{X} 2$ receptors by autocrine stimulation; (2) additional amplification by $\mathrm{P} 2 \mathrm{Y} 1$ purinoceptors on Receptor cells excited by ADP generated by the robust ecto-ATPase expressed throughout the taste bud (Bartel et al., 2006; Huang et al., 2009); (3) ultimately, elimination of secreted ATP by the ecto-ATPase; and finally, (4) negative feedback from serotonin released by Presynaptic (Type III) taste cells (Huang et al., 2009).

Additional factors contributing to the loss of taste-evoked transmitter secretion in mice lacking $\mathrm{P} 2 \mathrm{X} 2$ and $\mathrm{P} 2 \mathrm{X} 3$ receptors include the possibility that knocking out these genes affects the expression of other genes that are coordinately regulated and that participate in taste-evoked transmitter secretion (Iacobas et al., 2003; Sladek and Song, 2008; Singh et al., 2009). Our examination of a few likely candidates [TRPM5 and Px1 (this paper) and gustducin, P2X7, and T1Rs (Finger et al., 2005)] did not reveal any obvious defects. However, we did notice a decrease in PLC $\beta 2$ expression in DKO mouse taste buds that might contribute to the loss of taste signaling but may also merely reflect a decreased number of Receptor cells in taste buds. We have not quantitatively tested this possibility. In any event, tastant-evoked calcium responses in DKO mice did not differ from those in WT mice. Finally, knocking out $\mathrm{P} 2 \mathrm{X} 2$ and $\mathrm{P} 2 \mathrm{X} 3$ may result in the loss of necessary retrograde signal(s) from the nerve fibers during the development and maintenance of taste buds. Transection of the taste nerves leads to rapid alterations in gene expression in the taste buds (Miura et al., 2004) with ultimate loss of differentiated taste cells (Farbman, 1969). Even simply blocking axoplasmic transport within the taste nerves results in functional and morphological loss of taste buds (Sloan et al., 1983). The absence of $\mathrm{P} 2 \mathrm{X} 2$ and $\mathrm{P} 2 \mathrm{X} 3$ receptors prevents activation of the taste nerves by taste stimuli (Finger et al., 2005); this loss of activity may lead to insufficient retrograde signals that contribute to taste transmitter secretion. The exact mechanisms by which neural activity may affect taste cell differentiation and function requires further study. In any case, we interpret the main defect transmitter release by taste cells in the DKO mice to be their loss of autocrine P2X2 on Receptor (Type II) taste bud cells with additional contributions as discussed above.

\section{References}

Barry MA (1992) Ecto-calcium-dependent ATPase activity of mammalian taste bud cells. J Histochem Cytochem 40:1919-1928.

Bartel DL, Sullivan SL, Lavoie EG, Sévigny J, Finger TE (2006) Nucleoside triphosphate diphosphohydrolase-2 is the ecto-ATPase of type I cells in taste buds. J Comp Neurol 497:1-12.

Bo X, Alavi A, Xiang Z, Oglesby I, Ford A, Burnstock G (1999) Localization of ATP-gated P2X(2) and P2X(3) receptor immunoreactive nerves in rat taste buds. Neuroreport 10:1107-1111.

Cao Y, Zhao FL, Kolli T, Hivley R, Herness S (2009) GABA expression in the 
mammalian taste bud functions as a route of inhibitory cell-to-cell communication. Proc Natl Acad Sci U S A 106:4006-4011.

Cheung KK, Burnstock G (2002) Localization of P2X3 receptors and coexpression with $\mathrm{P} 2 \mathrm{X} 2$ receptors during rat embryonic neurogenesis. J Comp Neurol 443:368-382.

Crowley HH, Kinnamon J (1995) Transmission electron microscopy of gustatory epithelium. In: Experimental cell biology of taste and olfaction: current techniques and protocols (Spielman AI, Brand JG, eds), pp 105114. Boca Raton, FL: CRC.

Dando R, Roper SD (2009) Cell-to-cell communication in intact taste buds through ATP signalling from pannexin 1 gap junction hemichannels. J Physiol 587:5899-5906.

Dando R, Huang YA, Roper SD (2010) Acetylcholine, released from taste buds during gustatory stimulation, enhances taste responses. Chem Senses 35:A2.

Decker DA, Galligan JJ (2010) Molecular mechanisms of cross-inhibition between nicotinic acetylcholine receptors and $\mathrm{P} 2 \mathrm{X}$ receptors in myenteric neurons and HEK-293 cells. Neurogastroenterol Motil 22:901-908

DeFazio RA, Dvoryanchikov G, Maruyama Y, Kim JW, Pereira E, Roper SD, Chaudhari N (2006) Separate populations of receptor cells and presynaptic cells in mouse taste buds. J Neurosci 26:3971-3980.

Dorostkar MM, Boehm S (2008) Presynaptic ionotropic receptors. Handb Exp Pharmacol 184:479-527.

Dvoryanchikov G, Tomchik SM, Chaudhari N (2007) Biogenic amine synthesis and uptake in rodent taste buds. J Comp Neurol 505:302-313.

Dvoryanchikov G, Huang YA, Barro-Soria R, Chaudhari N, Roper SD (2011) GABA, its receptors, and GABAergic inhibition in mouse taste buds. J Neurosci 31:5782-5791.

Eddy MC, Eschle BK, Barrows J, Hallock RM, Finger TE, Delay ER (2009) Double P2X2/P2X3 purinergic receptor knockout mice do not taste $\mathrm{NaCl}$ or the artificial sweetener SC45647. Chem Senses 34:789-797.

Farbman AI (1969) Fine structure of degenerating tast buds after denervation. J Embryol Exp Morphol 22:55-68.

Finger TE, Danilova V, Barrows J, Bartel DL, Vigers AJ, Stone L, Hellekant G, Kinnamon SC (2005) ATP signaling is crucial for communication from taste buds to gustatory nerves. Science 310:1495-1499.

Grynkiewicz G, Poenie M, Tsien RY (1985) A new generation of Ca2+ indicators with greatly improved fluorescence properties. J Biol Chem 260:3440-3450

Hacker K, Medler KF (2008) Mitochondrial calcium buffering contributes to the maintenance of basal calcium levels in mouse taste cells. J Neurophysiol 100:2177-2191.

Hallock RM, Tatangelo M, Barrows J, Finger TE (2009) Residual chemosensory capabilities in double $\mathrm{P} 2 \mathrm{X} 2 / \mathrm{P} 2 \mathrm{X} 3$ purinergic receptor null mice: intraoral or postingestive detection? Chem Senses 34:799-808.

Hayato R, Ohtubo Y, Yoshii K (2007) Functional expression of ionotropic purinergic receptors on mouse taste bud cells. J Physiol 584:473-488.

Huang YA, Roper SD (2010) Intracellular $\mathrm{Ca}(2+)$ and TRPM5-mediated membrane depolarization produce ATP secretion from taste receptor cells. J Physiol 588:2343-2350.

Huang YA, Roper SD (2011) Sour taste stimulates GABA secretion from mouse presynaptic (Type III) taste cells. 33rd AChemS Annual meeting. Abstract \#36.

Huang YA, Maruyama Y, Roper SD (2008a) Norepinephrine is coreleased with serotonin in mouse taste buds. J Neurosci 28:13088-13093.

Huang YA, Maruyama Y, Stimac R, Roper SD (2008b) Presynaptic (Type III) cells in mouse taste buds sense sour (acid) taste. J Physiol 586:2903-2912.

Huang YA, Dando R, Roper SD (2009) Autocrine and paracrine roles for ATP and serotonin in mouse taste buds. J Neurosci 29:13909-13918.

Huang YJ, Maruyama Y, Lu KS, Pereira E, Plonsky I, Baur JE, Wu D, Roper SD (2005) Mouse taste buds use serotonin as a neurotransmitter. J Neurosci $25: 843-847$

Huang YJ, Maruyama Y, Dvoryanchikov G, Pereira E, Chaudhari N, Roper SD (2007) The role of pannexin 1 hemichannels in ATP release and cell-cell communication in mouse taste buds. Proc Natl Acad Sci U S A 104:6436-6441.

Iacobas DA, Urban-Maldonado M, Iacobas S, Scemes E, Spray DC (2003) Array analysis of gene expression in connexin- 43 null astrocytes. Physiol Genomics 15:177-190.

Jacques-Silva MC, Correa-Medina M, Cabrera O, Rodriguez-Diaz R, Makeeva N, Fachado A, Diez J, Berman DM, Kenyon NS, Ricordi C, Pileggi A,
Molano RD, Berggren PO, Caicedo A (2010) ATP-gated P2X3 receptors constitute a positive autocrine signal for insulin release in the human pancreatic beta cell. Proc Natl Acad Sci U S A 107:6465-6470.

Kataoka S, Toyono T, Seta Y, Toyoshima K (2006) Expression of ATP-gated $\mathrm{P} 2 \mathrm{X} 3$ receptors in rat gustatory papillae and taste buds. Arch Histol Cytol 69:281-288.

Kaya N, Shen T, Lu SG, Zhao FL, Herness S (2004) A paracrine signaling role for serotonin in rat taste buds: expression and localization of serotonin receptor subtypes. Am J Physiol Regul Integr Comp Physiol 286:R649-R658.

Kinnamon JC, Taylor BJ, Delay RJ, Roper SD (1985) Ultrastructure of mouse vallate taste buds: I. Taste cells and their associated synapses. J Comp Neurol 235:48-60.

Kinnamon JC, Sherman TA, Roper SD (1988) Ultrastructure of mouse vallate taste buds. 3. Patterns of synaptic connectivity. J Comp Neurol 270:1-10.

Lu SG, Zhao FL, Herness S (2003) Physiological phenotyping of cholecystokinin-responsive rat taste receptor cells. Neurosci Lett 351:157-160.

Miura H, Kato H, Kusakabe Y, Tagami M, Miura-Ohnuma J, Ninomiya Y, Hino A (2004) A strong nerve dependence of sonic hedgehog expression in basal cells in mouse taste bud and an autonomous transcriptional control of genes in differentiated taste cells. Chem Senses 29:823-831.

Murata Y, Yasuo T, Yoshida R, Obata K, Yanagawa Y, Margolskee RF, Ninomiya Y (2010) Action potential-enhanced ATP release from taste cells through hemichannels. J Neurophysiol 104:896-901.

Murray RG (1993) Cellular relations in mouse circumvallate taste buds. Microsc Res Tech 26:209-224.

Nagahama S, Kurihara K (1985) Norepinephrine as a possible transmitter involved in synaptic transmission in frog taste organs and Ca dependence of its release. J Gen Physiol 85:431-442.

Nagai T, Delay RJ, Welton J, Roper SD (1998) Uptake and release of neurotransmitter candidates, $[3 \mathrm{H}]$ serotonin, $[3 \mathrm{H}]$ glutamate, and $[3 \mathrm{H}]$ gamma-aminobutyric acid, in taste buds of the mudpuppy, Necturus maculosus. J Comp Neurol 392:199-208.

North RA (2002) Molecular physiology of P2X receptors. Physiol Rev 82:1013-1067.

Ogura T (2002) Acetylcholine increases intracellular Ca2 + in taste cells via activation of muscarinic receptors. J Neurophysiol 87:2643-2649.

Pelegrin P, Surprenant A (2006) Pannexin-1 mediates large pore formation and interleukin-1beta release by the ATP-gated P2X7 receptor. EMBO J 25:5071-5082.

Romanov RA, Rogachevskaja OA, Bystrova MF, Jiang P, Margolskee RF, Kolesnikov SS (2007) Afferent neurotransmission mediated by hemichannels in mammalian taste cells. EMBO J 26:657-667.

Romanov RA, Rogachevskaja OA, Khokhlov AA, Kolesnikov SS (2008) Voltage dependence of ATP secretion in mammalian taste cells. J Gen Physiol 132:731-744.

Royer SM, Kinnamon JC (1988) Ultrastructure of mouse foliate taste buds: synaptic and nonsynaptic interactions between taste cells and nerve fibers. J Comp Neurol 270:11-24.

Shen T, Kaya N, Zhao FL, Lu SG, Cao Y, Herness S (2005) Co-expression patterns of the neuropeptides vasoactive intestinal peptide and cholecystokinin with the transduction molecules alpha-gustducin and T1R2 in rat taste receptor cells. Neuroscience 130:229-238.

Shin YK, Martin B, Golden E, Dotson CD, Maudsley S, Kim W, Jang HJ, Mattson MP, Drucker DJ, Egan JM, Munger SD (2008) Modulation of taste sensitivity by GLP-1 signaling. J Neurochem 106:455-463.

Singh H, Warburton S, Vondriska TM, Khakh BS (2009) Proteomics to identify proteins interacting with P2X2 ligand-gated cation channels. J Vis Exp 1178.

Sladek CD, Song Z (2008) Regulation of vasopressin release by co-released neurotransmitters: mechanisms of purinergic and adrenergic synergism. Prog Brain Res 170:93-107.

Sloan HE, Hughes SE, Oakley B (1983) Chronic impairment of axonal transport eliminates taste responses and taste buds. J Neurosci 3:117-123.

Starostik MR, Rebello MR, Cotter KA, Kulik A, Medler KF (2010) Expression of GABAergic receptors in mouse taste receptor cells. PLoS One 5:e13639.

Zhang Z, Zhao Z, Margolskee R, Liman E (2007) The transduction channel TRPM5 is gated by intracellular calcium in taste cells. J Neurosci 27:5777-5786.

Zhao FL, Shen T, Kaya N, Lu SG, Cao Y, Herness S (2005) Expression, physiological action, and coexpression patterns of neuropeptide $\mathrm{Y}$ in rat taste-bud cells. Proc Natl Acad Sci U S A 102:11100-11105. 